\title{
Study on the Diversified Innovative Entrepreneurship Education Model of Colleges and Universities under the Background of Internet +
}

\author{
Wangwei \\ Recruitment and employment office,Dongying Vocational College,Dongyinf,Shandong,257091,China
}

Keywords: Internet plus; diversified; Innovation and entrepreneurship

\begin{abstract}
As a new concept of education in recent years, entrepreneurship education in college students emphasizes that entrepreneurial knowledge should be integrated into the classroom through diversified teaching methods so as to cultivate students' entrepreneurial awareness and entrepreneurial ability. And then internalizing this entrepreneurial spirit and ability to become their own literacy, accomplishing the entrepreneurial talents training objectives. Nowadays, many colleges and universities attach great importance to the mode of innovation and entrepreneurship education. Students are also very creative in starting a business. However, the entrepreneurial ability of students is not flattering. In addition, the faculty in this field is also is relatively deficient, and teaching level is relatively low. All of these make the innovation and entrepreneurship education model utopian, lacking of innovative practice. Since the reform and opening up, China's Internet information technology has made unprecedented achievements, which has poured into continuous support for university education and college students' employment to a certain extent. The advent of the Internet + has played a significant role in the innovation model of colleges and universities, it has influenced the innovation system of universities and provided a solid support for the construction of diversified innovation and entrepreneurship education model.
\end{abstract}

\section{Introduction}

Under the environment of internet + , there are more new changes in the innovation of classroom teaching in colleges and universities. Compared with the traditional teaching mode, the emergence of internet + brings great convenience to teachers' teaching. The development of our economy has accelerated the development of the Internet +, it has slowly penetrated into our lives and affected the development of each industry, prompting higher education in colleges and universities to face greater challenges, more new tests and tasks. China's industrial structure is also undergoing changes. Innovation-intensive industries gradually replace the old industrial structures in the past. Innovation leads to faster upgrading of industries. Both front-line management technologies and production technologies require innovative and entrepreneurial high-end talents. Therefore, no matter China or other countries, to train innovation and entrepreneurship-oriented students will be in the primary position of education innovation. All kinds of cultivation ideas are constantly pouring into teaching. If we want to occupy a place in the fierce national competition, our colleges and universities should constantly improve and update their diversified innovation and entrepreneurship education models.

\section{The present situation of innovation and entrepreneurship teaching modes}

The development of the Internet + has led to a more rapid economic development. The organic combination with the real economy has driven the expansion of consumer groups and consumer demands. At the same time, it has stimulated the employment demand and increased the number of 
jobs. The traditional manufacturing and processing industries are all accelerating the transformation of industries to keep up the pace with the development of the times and avoiding being eliminated by the market. This has led to more independent entrepreneurs, people in every corner of society and all fields are trying to play an innovative spirit, hoping to get more economic benefits and to achieve more achievements in business field. Nowadays, there are more and more talented people. Talents are rapidly changing in the trend of the waves behind drive on those ahead in the Yangtze River. However, the posts in each industry are basically in a state of saturation. Bachelors are not as scarce as they used to be and undergraduates are not uncommon. Many graduates find it hard to find jobs after graduation. Therefore, cultivating college students' capability of innovation and entrepreneurship is a good way to promote the employment of college students. In recent years, the Internet information technology in China has been developed very fruitful, people's work, study and life play an irreplaceable role. Meanwhile, it also brings a new development opportunity for college students to innovate and start a business, which also puts forward higher requirements on the entrepreneurial and innovative ability of college students. Students not only have to master the basic computer network technology, but also to constantly develop themselves, improve themselves and enhance the ability of innovation and entrepreneurship, which is not only an important goal of college personnel training, but also an important way for college students to achieve self-worth. Under the background of "Internet +", the sense of responsibility of college students has been enhanced, which is conducive to college students embody their personal value in society. Under the call of national innovation, colleges and universities should speed up the pace of diversified innovation and entrepreneurship education mode under the background of Internet + .

\section{Have no idea for innovation and entrepreneurship education of college students}

At present, most universities in China lack correct understanding of innovation and entrepreneurship education. In the process of teaching, they pay more attention to the cultivation of college students' professional skills, thinking only by mastering skilled professional skills can they lay a solid foundation for future career choice. Some universities believe that the success rate of college students' entrepreneurship is relatively low. If a specialized entrepreneurship and innovation course is set up, it will occupy a lot of class time. On the other hand, it will also spend a certain cost and the effect will be not obvious. Under the traditional teaching mode, students' knowledge about entrepreneurship is relatively simple and it is difficult to provide students with enough entrepreneurial opportunities. This shows that our colleges and universities lack understanding of student entrepreneurship and fail to integrate innovation and entrepreneurship into professional teaching, which reduces the success rate of college students' entrepreneurship in a certain extent. In addition, the curriculum in colleges and universities did not really put innovation and entrepreneurship education into practice. The concepts of innovation and entrepreneurship were lack of practical implementation in colleges and universities. And students lack a correct understanding of innovation and entrepreneurship. If we propose a specialized course without combining entrepreneurial and innovative skills, the teaching system will be not perfect and the mode will not be able to develop for a long time. It will die easily. There is no special course without professional teachers, which will result in a lack of teachers, and teaching levels are more mediocre. There is no direction for the cultivation of innovative and entrepreneurial ability of college students. In this case, the innovation and entrepreneurship education of college students will be impossible.

The mode of innovation and entrepreneurship education cannot keep up with the trend of the times

In our country, the mode of innovation and entrepreneurship education is very limited. First, 
professional training should be built on the professional base of the school. While training professional skills, carrying out imitating education and training for students' innovation and entrepreneurship ability. The mode that is attached to school and curriculum is not suitable for the current form of innovation and entrepreneurship. Second, continue using this form of operation without changing the old model of innovation and entrepreneurship and only adding innovation and entrepreneurship teaching to this mode of operation, teachers' teaching methods are still focus on objective knowledge, examination forms are only papers, such a lack of practical training mode is just like the "dumb English". Students can write and be on the exam questions, but they will not be applied to real life. Third, inducing the government's call for the reform in accordance with the government's policies. The government will allocate funds to help colleges and universities to achieve innovation and entrepreneurship transformation. At the same time, it will create a variety of innovation and entrepreneurship competitions, and encourage students to work hard to start their own businesses by financial incentives. Some achievements have been made under this reform, but the problem is still more than the result. The mode of innovation and entrepreneurship has not yet formed a variety of cooperation. Schools, government and social enterprises are still divided, and single school education is still unable to meet the requirements of innovation. Nowadays, with the Internet+ of things environment, it is accelerating innovation in all aspects and the technologies needed are more and more advanced. If students want to integrate into this environment, they need to study more advanced entrepreneurial technologies.

\section{The innovation and entrepreneurship is more in the form of than content}

Students need a good entrepreneurial platform in order to better play a creative ability, but the lack of entrepreneurship platform in colleges and universities resulting in college students only learn business-related knowledge from the textbook. Although colleges and universities also carry out competitions such as social etiquette classes and workplace psychology in order to promote the entrepreneurial ability of college students, they regularly organize seminars and organize students to participate in entrepreneurship competitions. It can arouse students' and schools' concern about entrepreneurship, however, most of the business plans are in the ideal state, it doesn't combine the actual development of the current market. And The feasibility and maneuverability are not good enough. Although some colleges and universities have set up entrepreneurial education activities, the overall operation is not standardized, strict and more formalized. It not only fails to provide a platform for students to exercise but also reduces their interest in entrepreneurship. The form is more stressed than the content, so the innovation and entrepreneurship education model can not be carried out continuously. In addition, colleges and universities have limited funds to set up an entrepreneurial platform and can not establish a centralized construction of innovation and entrepreneurship. As a result, the innovation and entrepreneurship education model in colleges and universities lacks an educational basis and can not provide comprehensive help for college students to start their own businesses. Lacking of cooperation between universities and enterprises can not integrate entrepreneurial knowledge, activities, training and practice into an entrepreneurial

platform. Without real experience of innovation and entrepreneurship, students' comprehensive innovation quality can not be improved. Although college students have learned the theoretical knowledge in colleges and universities, they must accumulate experience skills from the ground up after coming to society. They are unable to realize the expectation of successful employment after graduation. Therefore, it is necessary to strengthen the construction of entrepreneurship education mechanism. 


\section{The role and effect on the mode of innovation and entrepreneurship in colleges and universities under the background of Internet+}

The idea of "Internet+" was first proposed in 2012 and the concept of "Internet + " was first disclosed to the public in 2014. It is not simply to add "Internet+" to the traditional industries, but when in the integration of traditional industries, adding advanced information technology into traditional industry, and the most important innovation is transmitted to the outside world through the Internet platform. "Internet+" can summarize all the resources in the traditional industries, make reasonable adjustments optimize the structure and drive the cooperation among enterprises so as to promote the innovation and development of the industry.

All colleges and universities have also seen the influence of "Internet+". The continuous development of the Internet has enabled colleges and universities to use their technology to promote the improvement of innovative and pioneering education models, to obtain more flexible education models and spend less money to bring the greatest teaching benefits.

\section{The concept of diversified innovation and entrepreneurship mode}

Nowadays most people do not understand the innovation and entrepreneurship education mode correctly. It is simply attributed to the reduction of employment difficulties and increase the cultivation of innovative entrepreneurs. This has led to the innovation and entrepreneurship education mode becomes a personalized education to cultivate a small number of special education students, as well as to become a life-saving straw for college graduates. This kind of misunderstanding plays an obstructing role for the students to truly learn the essence of innovation and entrepreneurship education. At this time, teachers are required to change their teaching strategies, to teach the correct concept of innovation and entrepreneurship education and systematize their contents. This misunderstanding will dissipate.

Under the background of "Internet +", the education goal of innovation and entrepreneurship education can be clearer, and it is easier to achieve the expected effect in classroom teaching. Nowadays, the fast-growing society is no longer satisfied with the traditional forms of education. This kind of textbook knowledge explanation and skill training just can't keep up with the trend of the times. Now, more attention is paid to individualization, creative thinking, and the values of the times. Under such circumstance, innovation and entrepreneurship education should aim at the all-round development of undergraduates. We should change the traditional answering questions and doubts, pay attention to the inner world of undergraduates, the sensitivities to the surrounding things and personal opinions of college students, and accurately judge the inner changes of undergraduates.

Outstanding teachers can not only teach more rich, profound knowledge, but also find a good teaching method. Therefore, colleges and universities should pay more attention to the teachers in the innovation and entrepreneurship education. The colleges and universities can no longer be without a dedicated teacher of innovation and entrepreneurship education as before and without corresponding teaching aids and innovative practice platform. Besides, the choice of teachers should be investigated from many aspects, such as teachers' knowledge level, experience level, guidance experience and resources ability, so as to create a team of teachers with innovative and entrepreneurial ability.

\section{Diversified education system}

Bringing innovation and entrepreneurship education into the innovation plan of education and teaching in colleges and universities. Under the background of "Internet +", putting this plan faster on the agenda to faster and more clear the diversified innovation and entrepreneurship education courses and to give a clear presentation of the teaching content. From the basic point of the 
curriculum system, the relationship between the classes is closer and more fluent. Under the background of "Internet +", colleges and universities must build a perfect platform for innovation and entrepreneurship service for undergraduates, integrate them with the practical development of institutions and social needs, give full play to the organizational strength of all fields, and organically integrate the teaching resources of scientific research platforms, integrate the Internet knowledge into the course of physical education, establish a service center that integrates student management, service and entrepreneurship education. And recruit information should be published in the platform, so that students can learn the latest recruit information, and take the initiative to participate in the experimental group. In addition, with the support of "Internet + " information technology, students can summarize and analyze innovative projects and graduation projects. Moreover, the school can understand students' entrepreneurial intentions and employment intentions in the network center, conduct targeted entrepreneurship education for students to enhance the enthusiasm and initiative of entrepreneurship. The design of the teaching link is the test of the teacher's classroom teaching ability and the good link design can better connect the interaction between the classes. We should design more diversified innovation and entrepreneurship teaching links, integrate teaching ideas, innovative technology and skills knowledge, and help students absorb internalization step by step. We should make good use of the innovation education platform, expand the practice opportunities, strengthen the reality and cooperation of practice, and improve the diversified educational system.

\section{Conclusion}

In summary, the construction of innovation and entrepreneurship education mode in colleges and universities under the background of "Internet +" can better cultivate college students' overall entrepreneurial ability. In the innovation and entrepreneurship education model, we must start from creating ideas to implementing innovation mechanisms and gradually achieve the diversification of results. "Internet $+"$ has changed people's lives and changed the mode of operation of economic markets. However, the true content of the market has not changed. This requires the university students to innovate the product research and development and improve the quality of the products after the innovation and entrepreneurship education. The diversified innovation and entrepreneurship education will better play the greatest social benefits, accelerate social development.

\section{References}

[1]Chen Churui.Construction of Diversified Innovative Education Model in Colleges and Universities under the View of Internet+ [J].Journal of Guangdong Second Teachers College,2016,(04):38-44.

[2]Chen Lixin.Practical Research on Innovative Education in Colleges and Universities - Under the Background of "Internet +" [J]. Journal of Inner Mongolia Agricultural University (Social Science Edition),2017,(01):75-79.

[3]He Miao,Wang Ting,Wang Baoyu.Research on Innovation and Entrepreneurship Education in Colleges and Universities under the Background of "Internet +"[J]. SME Management and Technology (Early),2016,(07):128-129. 